\title{
Kierkegaard, Seduction, and Existential Education
}

\author{
Herner Sæverot
}

Published online: 6 April 2011

(C) The Author(s) 2011. This article is published with open access at Springerlink.com

\begin{abstract}
This article aims at making a case for the role of seduction in existential education, that is, education that focuses on the pupil's life choices. First, the article attempts to show that the relationship between the teacher and the pupil can be understood as a form of seduction. Secondly, the article examines how such a relationship functions in practice. Thirdly, the article warns against dangerous aspects related to seduction, and lastly, the article offers five conditions for how seduction can be used in a justifiable manner in existential education.
\end{abstract}

Keywords Seduction · Pedagogy $\cdot$ Existential education $\cdot$ Communication · Kierkegaard

With regard to existential issues about attitudes to life, freedom, responsibility, meaning, choice, and values, how can the teacher meet the pupils? How should the teacher meet the pupils who, for example, has created a connection and understanding for their own way of living through engaging meeting with certain macho ideals from Hollywood movies? In such a situation it would be clearly tactless for the teacher to suggest that the pupils bases their life upon an illusion and that they ought to choose another direction in life. Inevitably this would perhaps be understood as a provocation and the pupils would most likely put up a strong defence. This consequently would result in two opposing attitudes creating a distance between the pupils and the teacher. The teacher's direct thrust may even have strengthened the pupils' present attitude. ${ }^{1}$

In a Kierkegaardian perspective a seductive thrust can succeed to a greater degree when one acknowledges that there is always an uncertainty connected to the education of another

1 This example is a modernised and pedagogically contextualised version of the examples Kierkegaard presents in $\S 2$ of the first chapter of the book The point of view for my work as an author.

H. Sæverot $(\bowtie)$

Department of Education, University of Bergen, PB 7807, 5020 Bergen, Norway

e-mail: herner.saverot@psych.uib.no 
person. Kierkegaard underlines that one can never force upon another a meaning, persuasion or belief (Kierkegaard 1859/1998, p. 50). It is always the other person who must take the final leap into a new attitude to life. The teacher must not reprimand the pupils but take them seriously, be an attentive listener and slowly but surely add something that enriches the pupils present form for existence. This is the kind of seduction where the teacher can ensnare the pupils, making them aware of and perhaps interested in another perspective which challenges their present attitude to life. This seduction therefore has consequently a slight connection to education as it can lead the pupils into an educational process that questions their present attitude.

Nevertheless, we must not forget the following: As soon as one introduces seduction into pedagogy, problems emerge. In order to clarify some of the central problems I will, in this essay, turn to Kierkegaard. Kierkegaard's pedagogic starting point was as follows. He maintained that the Christians in his lifetime were seduced and therefore had persuaded themselves that they were Christians, when in reality they were not (Kierkegaard 1859/ 1998, p. 47). A central pedagogic question for Kierkegaard was how it is possible to get the seduced Christians out of their misunderstanding and at the same time get them to realise the necessity of higher life forms, the ethical and religious forms for existence. One answer was to capture these people so that they are given an opportunity to release themselves from their point of view and so choose another way of living. This can be achieved through what Kierkegaard called "aesthetic portrayal," which involves seduction (ibid., p. 51). This is how Kierkegaard saw an opportunity to reach those people who had convinced themselves that they were Christians, while in reality they lived as "aesthetes," concerned with immediate sensations and pleasure.

An important point with reference to the pedagogic art of seduction, is that Kierkegaard had to begin where they were; namely, in the aesthetic life form in order to reach out to them and further to challenge them to choose another direction in life. Nonetheless, in this essay I will not discuss how people who imagine they are Christians can convert to 'real' Christianity. I will, in other words, not limit myself to Kierkegaard's religious-existential project, but I shall construct a pedagogic proposal that looks at the whole in a greater existentialist perspective, where the Christian existential form can be seen as one of many forms for existence.

My main question is what the role of seduction in existential education is. I will address this question in four steps. Since seduction is a dangerous measure I will first ask what the dangers of seduction are. I will then explore what seduction's potential for existential education is. In the book The point of view for my work as an author (1859), which was first published after Kierkegaard's death, we find yet another problem connected to seduction's role in existential education which has to do with the fact that the aim of seduction and deception is to bring about demystification. A "demystifier," according to Biesta (1998), is someone who believes he can remove other people's delusions. The problem here is that the demystifier assumes that other people live in an imaginary world while he himself possesses the truth. Therefore I ask, in the final step, what kind of seduction can be used in existential education.

In addressing these questions I shall, firstly, attempt to show that the relationship between the teacher and the pupil is a form of seduction. Secondly, I shall attempt to show how such a relationship functions in practice. Thirdly, I shall warn against dangerous aspects related to seduction, and lastly, I shall give some 'rules' or conditions for how seduction can be used in a justifiable manner in existential education. 


\section{Existential Education}

In the book Fear and trembling (1843) Kierkegaard's pseudonym Johannes de Silentio dismantles Hegel's concept of education (in German: Bildung) as he believes that this concept brings about conventional and bourgeois individuals. The reason is, according to Kierkegaard, that the individual must put himself aside in order to advance culture. As an alternative to the idea of education as cultivation, de Silentio introduces an existentialist view of education.

What, then, is education? I believed [sic] it is the course the individual goes through in order to catch up with himself [at indhente sig selv], and the person who will not go through this course is not much helped by being born in the most enlightened age. (Kierkegaard 1843/1983, p. 46; my emphasis)

This indicates that one will not be oneself by incorporating cultural values and norms as Hegel maintains. Rather, one must be involved with what Kierkegaard calls "catching up with oneself." This means searching back to how one was before culture began to influence one's life. Kierkegaard wants the individual to take a critical distance to the culture, so that the process of individualisation can take place, more or less, without cultivation or socialisation. As the individual goes into this process, he may be himself anew. The core for this form of existential education, seen from the teacher's perspective, is to cultivate the individual's specificities, its singularity and uniqueness, which Kierkegaard in 1854 described as 'distinctiveness' (in Danish: Eiendommelighed; see Garff 2008a, p. 132). According to Kierkegaard our distinctiveness has been given to each of us by God (ibid., p. 129). Kierkegaard's God is not a friend of the bourgeois or of conventionalism, but has a weakness for the marginal, those who do not immediately fit into certain cultural circles (ibid., p. 117).

Against this background it is possible to interpret Kierkegaard as believing that each person is already unique because God is the one who gave everyone his or her unique characteristics. Such an interpretation implies a form of existential education which is about cultivating unique characteristics that are already in the individual. Although this may be true, one can also read Kierkegaard's text in another manner. In fact, Fear and trembling shows that people can catch up with themselves, that is to say that they can become redeemed and saved from their current existence, through an outer force. As when Abraham was about to offer his son Isaac, God stepped in and stopped the sacrifice. This example makes it possible to say that Kierkegaard's pseudonym de Silentio rejects every question about what people are. This is supported by Westphal (2008, p. 25), who says that Kierkegaard, like Levinas, contradicts Socrates' idea that the learner already has the truth within. Furthermore, an absolute inestimable power, God, called Abraham who answered, and in the moment Abraham accepted the call, he had been singled out (see Davenport 2008). In other words, it is God who singles us out, or, individualises us (see Caputo 2008, p. 19).

Of course this form of education, which can be derived from Kierkegaard's texts, is very specific. Nevertheless, we can see a certain relationship to a more modern form of pedagogy. In that context I think of Biesta's (2009) three functions of education which, as he argues, can also be understood as three possible domains of educational purpose. One function of education has to do with qualification, in which the individual shall be qualified for something specific. It can, for example, be about qualifying the individual for a profession. Another function has to do with socialisation, where the purpose is to insert each individual into existing social, cultural, political and other orders. Neither of these two 
functions can be related to Kierkegaard's notion of education. He is neither interested in qualifying or socialisation. In fact, he argues that individualisation must take place outside any form of socialisation or cultivation. This means that we can place Kierkegaard's existential education in the function Biesta (2009) describes as the subjectification function/domain. Biesta (2009, p. 356) says that this function can best be understood as the opposite of the socialisation function of education. The reason is that the individual should not be part of an already existing order, but should rather become independent from such orders. It would be wrong to talk about an objective truth when it comes to the individuation or subjectification of people. Rather, it is a matter of subjective truth. The difference between these two forms of truth is as follows. On the one hand, we can imagine the person to qualify as a doctor. It is essential that a doctor knows the objective truth about the human anatomy for instance. Therefore, a medical study, similar to other studies, must contain a great deal of qualification, where medical students must strive to get the objective content right. When it comes to existence and how to live life, however, one must think differently. One can not tell the person that s/he must live in a certain way. Of course one can point out some ways for the person, but, and this is the salient point for Kierkegaard (1846/1992), the individual must choose on his or her own. As soon as the existential choice is made, the individual must appropriate the truth, inscribe it in his or her life (see Caputo 2008, p. 64). This is no universally valid truth, but rather an existential truth, or, as Caputo (2008, p. 61) refers to as "the truth that is true for me."

In this way a range of pedagogic challenges occur, for example: How can one make an individual a new attitude to life? How is it possible for a teacher to both remain intentional, and yet engineer a free choice? As I have already argued, one apparently won't get very far by speaking convincingly to the intellect about the excellence of one way of existing. What then? Should the teacher simply give up? Yes, either that or one can appeal to something that lies 'deeper' in the pupil than the rational consciousness. This can be done via existential seduction, because it is a non-rational and unpredictable communication form that can lead us away from ourselves almost without us noticing it, and over into a path we perhaps in the beginning have no desire to take. Of course one is taking a risk planting seeds in the pupils unconscious that are in direct opposition to the pupils conscious wishes. One is in danger of leading the pupils astray. It is precisely here that the ethical boundary becomes relevant, something we must not close our eyes to. Nevertheless, seduction can be pedagogically valuable, and this has, in part, to do with that it has a magical power that we do not understand-a power with the ability to bring about a fascination for something. ${ }^{2}$ I see now that an explanation is needed in regards to what is meant by Kierkegaard's notion of seduction, notably from $a$ particular point of view.

\footnotetext{
${ }^{2}$ I am fully aware that the notion of existential education, as I am about to define it, is reminiscent of liberal education, as for example Arcilla defines the latter notion in his book For the love of perfection: Richard Rorty and liberal education. Let me thus clarify that there are certain differences between the two notions of education. In the mentioned book Arcilla discusses liberal education in the context of Richard Rorty's educational philosophy. To avoid and disarm the antagonism and hypocrisy of culture he forms a specific notion of education; viz., conversational edification (Arcilla 1995, p. 105). The difference between Arcilla's views on liberal education and the notion of existential pedagogy that I highlight is shown where he, as I see it, abandons Rorty's concept of irony. That he does, I take it, where he seeks to connect the conversational education to a kind of moral perfectionism (ibid., p. 132; see also Biesta 1997, p. 87). In my view, Arcilla's faith in the good and perfect becomes too certain, so that a teacher, for example, can easily point out the direction in which the pupil should go. The existential education, on the other hand, is more about challenging-for example through seduction-pupils' position in life, rather than guiding them to another position in life.
} 


\section{Seduction: Eroticism, Spirituality, and Deception}

In the book Either/Or (1843) it is stated that in the main there are two ways to seduce. One is the immediate/erotic seduction, and the other is the spiritual/intellectual seduction.

\section{Eroticism}

In The immediate erotic stages, included in Either/Or, Don Giovanni is characterised as an immediate seducer who seduces through the erotic. He is like music that disappears just as fast as it is played. The power of the word is totally foreign to him. The only thing he cares about is to seduce in a spontaneous manner. He always moves from one woman to another and ends up having seduced 1,003 women (a number that indicates that he continues to seduce). Apart from this one must be very careful calling Don Giovanni a seducer, says A (Kierkegaard's pseudonym in this text). But Don Giovanni is only in a certain way and to a certain extent a seducer.

He enjoys the satisfaction of desire; as soon as he has enjoyed it, he seeks a new object, and so it goes on indefinitely. Thus he does indeed deceive, but still not in such a way that he plans his deception in advance; it is the power of the sensuous itself that deceives the seduced, and it is rather a kind of nemesis. (Kierkegaard 1843/ 1987, p. 99)

The actions of Don Giovanni are characteristic of a deceiver rather than a seducer, butand this is the salient point-his deception is vulgar because he lacks both sly preparation and thorough planning.

\section{Spirituality}

Faust is a different seducer than Don Giovanni. He can be said to be an intellectual seducer. In contrast to Don Giovanni, Faust is unmusical. His weapon is first and foremost the word, which is also the chief weapon of Johannes, the main character in The seducer's diary (which is incorporated in Either/Or). More correctly, Johannes combines both forms of seduction-even though he characterises himself as an "aesthete, an eroticist" (Kierkegaard 1843/1987, p. 368). It is this combination which makes him particularly powerful and dangerous. This is evident in the last phase of his seduction of Cordelia. In the heat of the duel the young woman attempts to seduce Johannes with erotic means only (ibid., p. 411). She has only one weapon at her disposal. Johannes, on the other hand, has two weapons, the erotic and the spiritual. "Sometimes one must place oneself very high, yet in such a way that there remains a place still higher; sometimes one must place oneself very low." (ibid., p. 400). Johannes knows when he shall place himself on a higher and spiritual plane and when he shall put himself on an erotic and lower plane. But first and foremost he bides his time. He doesn't sprint like Don Giovanni. On the contrary, he plans his actions so that he can be one step ahead of his victim and, also to be able to "gaze into her future" (ibid., p. 355). The seducer par excellence combines the erotic with the spiritual. That is to say that the seduction is both immediate and-first and foremostprolonged (see Garff 2008b), as both planning and the use of tricks are an important part of the seduction. 
Deception

Deception is also used in seduction. Johannes admits that he likes to

keep the listeners to my story in suspenso by means of minor actions of an episodic nature to ascertain how they want it to turn out, and then in the course of the telling to fool them. My art is to use amphibolies so that the listeners understand one thing from what is said and then suddenly perceive that the words can be interpreted another way. (Kierkegaard 1843/1987, p. 370)

It is difficult to separate deception from seduction, because they merge with one another. Nonetheless it is possible to make a distinction between them. As seducer, Johannes meets the audience face to face, which is necessary when the aim is to capture the attention and empathy of others. Through "minor actions of an episodic nature" an erotic energy is created, whereupon the listeners are ensnared by Johannes's trap. In such a manner they are disarmed, they are in his grasp and can now listen in anticipation. At the same time he deceives them. This happens as he starts to create confidence. He gives the audience the impression that he will explain the rumour that he has consciously spread about. In this manner the audience and Johannes appear to follow the same rule. But as soon as trust is established the deceiver changes the rule without the audience being aware of it. He goes behind their backs, as his deeply held secret intention is to create a false impression. Here we find perhaps the greatest difference between seduction and deception. As a seducer, Johannes meets his opponent face to face-such that a relationship occurs between them. As a deceiver, on the contrary, he goes as it were behind his opponent's back. There he can go unnoticed-provided the seduction has been successful. In other words: if he has managed to catch the audience's attention they will most likely not notice what is going on behind their backs.

In Either/Or Kierkegaard thus shows that seduction can combine the immediate and the erotic with intellectual processes, and also with deception. Before I turn to the question how seduction can be employed in existential education I will discuss some of the dangers of seduction.

\section{The Dangers of Seduction and Its Potential for Existential Education}

The seducer's diary shows us a person who, as a seducer, goes too far. This text thus sets a clear boundary for seduction. Johannes takes no notice of this boundary. He divorces himself from so called "vulgar seducers," for example a judge who gives sinners false promises of freedom if they confess (Kierkegaard 1843/1987, p. 367). Such a person uses only his power and his talent, instead of finding out where the other stands, and so begin there. Johannes does just this. He does not begin with what he himself believes and thinks about various matters; rather, he begins with what Cordelia says and does, in order to gain valuable insight in her world. Then he can use this insight against her, just as if it comes from her and not him. In this way the seduction can happen without the victim noticing it. To begin with what the other says and does is not in itself unethical because it is a way to gain knowledge about the other. Johannes, however, abuses this knowledge when Cordelia's own views on various matters become the threads he uses to spin her into his web. Consequently he can, in contrast to the vulgar seducer, get his victim to believe that she acts in accordance to her will, when in reality it is his will that controls her actions. For example, Johannes gets Cordelia to break off their engagement. As a consequence of 
slyness and quick wits he gets her to believe that she does this according to her own free will. In reality, however, her actions clash with her own will. Johannes seduces in such a way that the victim gives him what he wants. With Johannes, his aim is to seduce in order to attain physical pleasure. Rather than evil intent, Johannes seems to display narcissism and a lack of empathy and compassion. It is here that seduction manifests its destructive force.

If we transfer this example to a pedagogic context, we can begin to see some of the problematic implications of using seduction. One is that a seducer always is in danger of ruining the life of the seduced, even though the seducer may believe that $\mathrm{s} /$ he is living a lie. The Norwegian dramatist Ibsen, who in many ways was greatly inspired by Kierkegaard, said it in an appropriate manner in his play The wild duck (1884/1991, p. 192; my translation): "Take the illusions from the average person, and you take happiness from him at the same time." Ibsen observed in his time that many people live in their illusions, or in other words, they compose a world that they perhaps consider is better and safer than the world they in reality live in (see Cappelørn 2010, p. 159). The seducer must therefore address different questions, such as whether it is appropriate to try to seduce a person away from their illusions, or not. Confronted with such situations, Kierkegaard chose not to intervene for fear that he would take from the seduced Christians something that was, despite everything, an important anchor in their lives (see Garff 2000). Furthermore, a seduction can, in the worst scenario, lead to a complete delusion and perhaps even to brainwashing as we see in the example from Strasser's novel The wave (1981). Through a mental and seductive game the history teacher in this novel brainwashes some of his pupils, and this ends with him leading them to act like Nazis. We can say that seduction at its most destructive is when the teacher manipulates the pupils into his own world (see Kierkegaard 1846/1992, p. 74ff.). As soon as there isn't space for other points of view than the teacher's, he is about to indoctrinate the pupils (see Spiecker and Straughan 1991), while at the same time hindering the pupils from being free to choose for themselves.

On the other hand, the seducer must give the pupils a free choice, because the existential education focuses on what Kierkegaard says in Works of love (1847), "to become himself, free, independent" (Kierkegaard 1847/1995, p. 274). The individual can only become himself, free, or, independent by taking the existential choice on his own, and then inscribe the existential or subjective truth in his own life. The point is that the individual can not live someone else's truth about existence. From an educational perspective, the individual can only become himself provided the teacher's intervention is unnoticed. In Works of love Kierkegaard explains how the existential education ought to happen by presenting two sentences: 1. "This person is standing by himself through my help" (ibid., p. 274); 2. "This person is standing by himself - through my help" (ibid., p. 275). The sentences are nearly identical apart from one difference. The second sentence has a dash, which can perhaps appear unimportant, but that little dash makes a significant difference when considering existential education. Why might that be so?

The first sentence says that the pupil doesn't really stand on his own legs. Instead of standing on his own he is reliant on the teacher's help-that really hasn't helped the pupil. The teacher has, according to Kierkegaard, only deceived the pupil, that is, deceived in a vulgar manner. What I am trying to point out is that the teacher has been too direct in his communication and thereby forced the pupil into an objective truth. But what if the teacher, contrary to expectation, has managed to talk a pupil who was influenced by a macho form of existence out of this? The pupil has apparently become free thanks to the teacher's direct help, but after all the help is only a deception. For Kierkegaard the pupil 
has not become himself in this manner. It can only happen when one makes the choice to change to a new attitude to life by oneself. The teacher must therefore 'know' how a gift should be given (see also Derrida 1996, pp. 74-77; Wimmer 2001, pp. 164-167). Above all he must not approach in a manner that will make the pupil feel indebted to him.

The second sentence, on the other hand, says that the pupil really stands on his own legs. This has to do with the teacher 'knowing' how a gift should be given, that is, he helps the pupil who does not see the help. The help is hidden and must remain hidden or the pupil will not gain independence. In other words, there must be seduction and deception, but not of a vulgar sort. It is more about what Kierkegaard describes as "to deceive the other into the truth" (ibid., p. 277). It is important to note that this does not concern some kind of objective truth. The truth Kierkegaard talks about is not universal for all time and everyone. Rather, it is a notion of subjective truth (see Walsh 2009, pp. 34-35). This means that the teacher's pedagogic assignment is not about bringing the pupil to his truth because that would only be his own subjective and personal truth. All the same, the teacher must, in a seductive and tactful manner, get the pupil to see his side of the situation. But the teacher's view, as stated, is neither general nor universal. He is even sceptical about his own beliefs and opinions (Kierkegaard 1846/1992, p. 85). ${ }^{3}$ What it is really about is to deceive or bring the individual pupil to the edge, as it were, but it is the singular individual-hiin enkelte-who must cast himself "out on [sic] 70,000 fathoms of water" (Kierkegaard 1845/1988, p. 470). The pupil shall not be deceived into the teacher's truth, but into his own, subjective truth that must never be total (Kierkegaard 1846/1992, p. 85). According to Kierkegaard, this teacher is doing everything for the pupil, but pretends he is doing nothing. He takes no credit for what has happened; rather, it is a total self sacrifice, about the same as working without pay (Kierkegaard 1847/1995, p. 276). Briefly it is about giving "in such a way that the gift looks as if it was the recipient's property" (ibid., p. 274). In this way the teacher has managed to create an opening where the pupil is given the opportunity to make the existential choice on his own. This can first happen provided the teacher's intervention is unnoticed.

Have we not here an example of an invisible form of coercion, or can we say that a coercion that is done in secret is not coercion? I would actually say that a coercion that goes unnoticed is a worse form of coercion than a coercion that is done openly. The Kierkegaardian seduction thus has certain limitations. Nevertheless, I believe that it is possible to solve this problem. To do this we must look closely at what the teacher hides. I imagine that it is about holding back words and actions that demand recognition and gratitude in return (see also Derrida 1996). This means that the teacher must act and speak in such a way that the recipient does not feel that he should thank or praise the teacher for the gift. In such cases, the gift is destroyed, because the one who offers the gift is in the center of the event. The consequence of this is that the recipient is led into a kind of existence that is controlled by the teacher. The former is not standing by himself but must rely on the teacher as if the latter was a crutch.

\footnotetext{
3 This occurs in Concluding Unscientific Postscript to Philosophical Fragments where Johannes Climacus separates between direct and indirect communication. To communicate directly with reference to existential issues is a deception, not only against God but also against oneself and another person (Kierkegaard 1846/ 1992, p. 75). The reason is that the direct communication presupposes certainty and result, something the existential never can be reduced to. Therefore, one must always communicate indirectly when it concerns existential issues. Each person who communicates in this manner is, therefore, "never a teacher, but a learner" (ibid., p. 85). This means that he always holds open the possibility to alter his view of life.
} 


\section{The Teacher-Pupil Relationship as a Kind of Seduction}

In Kierkegaard's book Practice in Christianity (1850) we meet yet another seducer. This seducer, as I shall argue, is more of an educational seducer, that is, he operates within the boundaries of what is justifiable in a pedagogic situation. Yet it is a seduction and therefore an example of a teacher-pupil relationship that is a form of seduction. I will first discuss this in general terms and then focus in on the educational dimensions in order to answer the question about the role and potential of seduction in existential education.

Anti-Climacus, who appears as the author of this book, provides his readers with a thought experiment. His discussion focuses on a child because its mind is not yet cluttered with too many prejudices. In other words, the child does not have to catch up with himself because he is still at a 'before-culture' stage of existence. Anti-Climacus begins the process of existential education by showing the child many different pictures. First he shows a picture of Napoleon which is followed by a story about the French emperor. Next he shows a picture of William Tell, also accompanied by a story. He continues to show other pictures, when suddenly the child's eye falls on a picture "that you have deliberately placed among the others; it portrays one crucified" (Kierkegaard 1850/1991, pp. 174-175). This is a prime example of seduction with a pedagogic purpose, as it is both intellectual due to the teacher's planning, and immediate due to the picture that seduces in a spontaneous manner. Why is this so? First of all because the picture was placed deliberately with the other pictures so that it becomes possible to capture the child's interest. Second, the picture, which shows a representation of Jesus on the cross, has, as I see it, a far stronger content than the other pictures which represent different heroic figures. This strange and raw picture can therefore, I think, move the child to a much greater degree than the romanticised hero pictures. Even if the teacher has seduced in this way, he has not forced Christianity, or a specific ethical-religious form for existence, on the child. He has been helping indirectly (Kierkegaard 1859/1998, p. 56), without the child noticing him. In this way the teacher has avoided appearing as an authoritarian and didactic figure that urges and instructs. Such a course of action, where the teacher is too visible and conspicuous in a situation where there is talk of education that focuses on the pupils life choices, will easily insult the pupils who consequently will not allow themselves to be captured and interested (ibid., p. 54). By being visible and at the same time invisible, the teacher can awaken the child's curiosity. In this case we even see that the child asks on his own initiative. The child wonders who the crucified is and what he has done, so the teacher is given an opening to follow up with a story that must be told "very vividly" (Kierkegaard 1850/1991, p. 176), that is, seductively. ${ }^{4}$

Here Kierkegaard's pseudonym Anti Climacus is very concerned that the Christian way of life, which we can consider as a specific form for existence, must not be forced upon someone against their will. Yet, as I read Kierkegaard, the existential education has to begin with a degree of planning. First, the teacher places, with knowledge and will, the picture of the crucified between the pictures of Napoleon and other heroes. Second, the teacher consciously chooses to place the romanticised hero pictures up against the raw and brutal picture. After having told of the murder of Jesus, he could only hope that the sight of Jesus on the cross would seduce and move so strongly that the child's own will would force

\footnotetext{
${ }^{4}$ Of course, the child can not be completely without knowledge, as it is necessary to obtain a certain understanding with regard to the content of the education. As I perceive Kierkegaard's pseudonym, the child does not know the history of Christianity, so that prejudices will not stand in the way of his future choice in relation to existence.
} 
him to want to convert himself. "You are not being compelled against your will, but blessed are you if your will compels you in such a way that you must say: I cannot do otherwise, for this sight moves me!” (ibid., p. 171).

Johannes of The seducer's diary, on the other hand, manipulates, and nothing more. This is because he undertakes a one-sided manoeuvre, that is, he seduces Cordelia until she has fulfilled his will. He tricks her, in other words, to do what he will. Therefore, it is not love. It is rather a narcissistic action because he seduces with the aim to experience the most possible physical pleasure.

Some might say that Anti-Climacus and Johannes are quite similar, for is it not just as narcissistic to seduce someone into Christianity as it is to seduce in order to experience pleasure? There are no clear-cut answers to such questions, but I believe that it is possible to trace an essential difference between these two figures, that is, a difference that is of great importance with regard to existential education.

Anti Climacus seduces also, but, as I see it, he undertakes a double manoeuvre. To begin with he leads the child towards a particular picture. Herein lies seduction and deception. If he had stopped with this, if he had only deceived, he would have appeared as Johannes, a deceiver and manipulator, and nothing else. By undertaking yet another manoeuvre, though, he becomes something more. He emerges, I think, as a teacher who takes his ethical responsibility. Right enough, he deceives the child but it is not about the doing of the teacher's will. Rather, the child is faced with a choice. The child must decide if he will follow his earlier will or change it. The teacher has entered love, as Kierkegaard $(1850 / 1991)$ defines it, because he is open to the possibility that the child will continue to live as before. This possibility must be there, or he will have become like Johannes-that is, a pure manipulator who only can use, or better still, misuse his authority - rather than giving it away. It is about giving the other person a choice, that is, one transfers authority to the other, who has the right to choose to make the change or not. This tells us that the teacher has really been in the sphere of love the whole time, also when he intervened. He intervened in the child's life, but he didn't do it for gain, unlike Johannes. Rather, he did it to serve and humble himself and at the same time lead the child's attention towards something new that he did not know before. He opened a new world that the child could choose to live up to in his own subjective manner-or no.

\section{Theoretical Reasons: Aesthetic Devices and Narration}

This example where the seduction has occurred through aesthetic devices (more specifically: pictures) and narration, is only a thought experiment. But theoretic reasons can also be given that offer a more elaborate answer about similar seductions and their role and potential in and for existential education. Let me take the reasons one after the other. First I will place the aesthetic devices within a theoretic framework, before I complete this section by doing the same with narration.

\section{Aesthetic Devices}

It could be argued that aesthetic elements in teaching have a magical power to steer people onto a path they may initially had not wished for or had not thought of taking (see also Eisner 2004). By giving seductive devices a prominent place, for example in the form of pictures, literature, music, aesthetic teaching speaks to a large degree to the sensual and the emotional. The strength of such sensual and aesthetic devices is that they often affect the 
whole existence of people, and they can therefore extend peoples contact with their surroundings, which indicates that the aesthetic devices speak to other aspects of people rather than the logic and concept orientated aspects (see also Adorno 1996). We cannot simply decide that we like an aesthetic expression or not: either its quality strikes us or it doesn't, and this may even happen independently of what we on a rational plane think about the aesthetic expression. This does not exclude, of course, that any form of aesthetic experience is related to the beholder's knowledge, prior experience, mood, and the like.

According to Adorno (1996) and others the aesthetic and seductive devices are context dependent, as that which fascinates one person doesn't necessarily have the same effect upon another. Yet, the chances of a successful seduction are probably better the more one knows a person. In other words, it is an advantage, in light of seduction, to have a certain knowledge about that which really means something in a pupil's life. Therefore, the teacher should, in certain contexts, begin where the pupils are (Kierkegaard 1859/1998, p. 46). However, we must not forget that little is more comical than adult people trying to talk the same language as young people, for example by taking a starting point in popular cultural references that, from the young people's perspective, are totally passé.

There is also, I believe, the strong possibility of catching the pupil's attention if the teacher, just as Anti-Climacus, provides the break in the pattern of the picture presentation by, for example, introducing a picture where the content is very different from the other pictures. Again, this is entirely dependent on the recipient, but as Kierkegaard says in one of his journals, to relieve a formal treatment of aesthetic topics in a presentation with less formal and lighter elements can have an educational effect (see Kjær 1986, p. 55). Such a change in the presentation can be compared with, says Kierkegaard, the chorus in a song or the comic parts in a romantic drama, where the effect can make a situation become more concrete and ordinary (ibid.). In this way it may be possible to capture the pupils' attention. This is, of course, only an example of how seduction may function in practice. There are no predetermined methods of how to seduce in the best possible way. I have only tried to argue that aesthetic devices can be seductive in themselves, and that the seduction can be further enhanced by presenting the aesthetic devices in certain ways. But that said, one can never ignore the fact that any form of seduction is dependent on the receivers and the context.

\section{Narration}

If the teacher would begin by using aesthetic elements this ought, in the light of AntiClimacus's example, to be followed by lively and, as I will emphasise, seductive narratives about these elements. A teacher who narrates and who fails to seduce will always have a large handicap. The narration will probably not find its way to the pupils. Although we should not underestimate the seductiveness of dry and direct narration (see Kierkegaard 1846/1992, pp. 516-517), the idea, from a Kierkegaardian perspective, is that the narration must be so seductive that the receiver experiences himself as being a participant. This is evident in Kierkegaard's very first book, where he criticises the writings of Hans Christian Andersen. Indirectly Kierkegaard says that Andersen, who is most known as a writer of fairy tales, is a bad seducer because he, time and again, steps out of the narration to comment and explain (Kierkegaard 1838/1997, pp. 24-25). Therefore, Andersen does not manage to pull his reader into the narrative, thus positioning the reader as a spectator to the event (ibid., p. 41, 51). Kierkegaard himself does not, in my view, lack the power of narration. Of course, one can not just say that a particular author is seductive. There are many factors that come into play, such as the reader's experience, mood and so on. 
However, when Kierkegaard is at his best it is as if the readers are swept into the worlds of other fictional people (see Billeskov Jansen 1951; Sløk 1993; Garff 2008a). It is as if we are on the inside of a drama where we feel ourselves as being participants rather than spectators. Kierkegaard's own narratives are sometimes so seductive that they are capable of sending the opponent into a drama that the he cannot control (Garff 2008a, p. 117). To be even more precise: the seductive and the aesthetic narrative can send the subject in two directions, out towards the narrative itself and down towards a passion that can be connected to the narrative (ibid., p. 123). One can say that the narrative has swept the reader into the drama that consequently has awakened the passion of the person. In this manner the narrative has presented a choice where the receiver can choose to be oneself anew, or not.

\section{What Kind of Seduction Can Be Used in Existential Education?}

So far I have discussed two examples. In the first I imagined a pupil who lived by certain macho ideals from Hollywood movies, and a teacher who saw this as an illusion. In the second I applied the thought experiment of Anti-Climacus in order to show existential seduction in practice. There is considerable difference between the two examples. In the first example the pupil is being led away from that which the teacher regards as an illusion so that the pupil can catch up with himself, whilst the second example is about a child who more or less is still 'before' the influence of culture. The seducer in the second example, therefore, does not attempt to lead the child away from anything. The aim is rather to lead the child into something, into a specific form for existence. Despite this difference there is also a similarity between the two examples. In the first, the teacher assumes that the pupil bases his life on a lie, which suggests that the teacher must have an opinion about something that is true, or at least truer, with reference to existentialist issues. So too in the other example, where the aim is to lead the child to a certain form of truth about being a Christian person. Even if it is the child's desire, and not the teacher's will, that shall force the child to take a new standpoint in relation to the ethical-religious form of existence, we still cannot avoid the problem that marks both examples. The problem is that both examples depict the teacher as one who has rather strong opinions about what is right and wrong in relation to existentialist concerns. This is perhaps shown even more clearly in The point of view for my work as an author: A direct communication, Report to history, where Kierkegaard aims at communicating in a direct manner. Apparently Kierkegaard presents himself in this text, or in parts of it, as a demystifier, that is, a kind of teacher who presupposes that other people are deluded while he himself possesses the truth.

Discussing the Foucauldian idea of 'counter-practice' Biesta (1998, p. 507) emphasises that "(a) counter-practice should not be designed out of an arrogance that it will be better (or that one claims to know that it will be better; once again: ignorance) than what exists." A teacher should, according to Biesta (1998), challenge his pupils, but he must not claim that his views are better than theirs. With Kierkegaard it can appear so. This is evident for example when he explains his deceiving strategy. According to Kierkegaard the teacher must not communicate directly with a person who is only a conceited Christian. Hence, one must not say: "I am Christian, you are not" (Kierkegaard 1859/1998, p. 54). To criticise the other directly in this fashion will only give favourable conditions for negative feelings that will hinder the opposition in rejecting his beliefs. The teacher must therefore speak indirectly: "You are a Christian, I am not Christian" (ibid., p. 54). In this way the teacher opens for the opposition to accept conversion to a new way of being a Christian. It can 
appear that Kierkegaard will demystify the other's way of being a Christian. It is just as if he says indirectly to the other person that he lives a Christian life in the wrong way, while he himself is a Christian in the true way. And from here the other person can potentially be led to the truth. "If you can do it, if you can very accurately find the place where the other person is and begin there, then you can perhaps have the good fortune of leading him to the place where you are." (ibid., p. 46) This statement can easily be understood as that Kierkegaard wishes to lure the other to a particular place which is defined beforehand-a place, moreover, where Kierkegaard is already waiting.

According to Biesta (1998), who doesn't speak about Kierkegaard, nobody has the right to claim that his mode of thinking or living is better or truer than that of others. Such an attitude is, of course, nothing less than arrogance. Nevertheless, some ways of thinking can be categorised as conceited, but then we end up in questions about truth. Take for example the pupil who maintains that the Holocaust did never happen. There is an infinite amount of evidence that the genocide of the Jews and other groups has happened, and there is altogether no ground to argue that it did not happen. The pupil who maintains that the Holocaust has been invented lives in a fantasy world, beyond all reality. Yet when the issue at stake is not truth but existence, then it is not so easy because existence is a matter of what Kierkegaard calls 'subjective truth,' which means that the way one chooses to live must be decided at the individual level. What can the teacher do in such cases? Biesta (1998) suggests that the teacher should challenge the other, but without claiming that the other's way of living is untrue. Furthermore, the teacher can only show "that the way things were was only one (limited) possibility" (Biesta 1998, p. 507). The teacher, in this case, doesn't communicate anything that suggests it is true, on the contrary, he communicates something that is different: "[a] counter-practice is only different" (ibid., p. 507). In this manner the opposition is given the chance to see things in a new and different perspective. The teacher, on his side, has avoided being reduced to a demystifier.

Concerning religious and existential issues, Kierkegaard suggests, in an extension to Biesta's argument, that the teacher must communicate indirectly, not only to avoid appearing as an authority and domineering figure, but also to open the situation so that the opponent can act with the intention of attaining his own subjective truth. This way Kierkegaard avoids the problem of demystification. Take, for example, this quotation from Practice in Christianity.

For example, it is indirect communication to place jest and earnestness together in such a way that the composite is a dialectical knot - and then to be a nobody oneself.

If anyone wants to have anything to do with this kind of communication, he will have to untie the knot himself. (Kierkegaard 1850/1991, p. 133)

This means, as I see it, that the communicator is both present and absent. He is present to intervene in another's life, that is, he intervenes and challenges the other. Moreover, as soon as the information has been communicated, he becomes "a nobody." But this doesn't mean that he leaves the stage. As we saw in the example from the thought experiment of Anti-Climacus, the teacher is there, together with the pupil. They share a commonality, but as two different individuals. At the same time each individual must untie the knot alone. Of course it is not possible to untie the knot only one way because it is dialectic, that is, the information, in itself, is no jest and, in itself, not earnest, but both aspects. Jests and earnestness - which are here used as examples-go dialectically into each other, so that the information avoids clarity and conformity. The pupil's destination is therefore not defined, and in this way Kierkegaard avoids being a demystifier. 


\section{Conclusions: Existential Seduction Without Coercion}

Readers may well disagree with my attempt to make a case for the role of seduction in existential educational. In my opinion, seduction is a rather unused and a little approved educational resource-which is understandable given the potential dangers of seduction. This is why we need to have certain knowledge about when seduction can be educative and how it can be used safely. By way of conclusion I will offer five conditions under which seduction can be used safely in existential education. ${ }^{5}$

\section{Respecting Pupils}

The most basic challenge a teacher must address with reference to existential education is the question of what can be an appropriate way of life for another person. How shall the teacher proceed when it involves such an existential concern? Should he try to seduce the pupils out of what he thinks are delusions? Within the confines of existential education considerations concerning the pupil's subjectivity must have precedence over the aim to adapt to culture and society. For example, the teacher must create the best possible conditions so that the pupils can try out their choices without direct intervention. Rather than becoming cultivated and socialised, the pupils must be given space for making their own experiences so that this will give them the opportunity to find for themselves their path in life. What seduction can effect in this context is awakening in the pupils the desire to ask questions about their subjective truth. In this way seduction can happen without coercion, or, to be more precise, the pupils are coerced to question their position in life, rather than being coerced into a particular position in life.

\section{Tact and Introspection}

Seduction presupposes a high degree of pedagogical tact. If teachers go ahead without due caution, without respect for the pupils' vulnerability and with too much confidence in one's own capabilities, one risks to make serious mistakes. Every teacher who utilises seduction must therefore continuously examine himself. A teacher with little introspection and too much confidence can even risk being seduced by his own seduction ability, with a result that is exceptionally unfortunate. Teachers must also be aware that the relationship between the teacher and the pupil is and will be a power relationship, where one part is a minor and therefore has a right to protection. Thus, it is also important that the teacher must be aware of the destructiveness and strong powers of seduction.

\section{The Value of Secrecy and Trust}

Seduction presupposes that pupils must not know the 'rules of the game,' because if they do the power of seduction will vanish. For the teacher this means that he has to be present and at the same time not present. If the teacher is too present, there is the great danger that the pupils will discover the seduction. In such circumstances everything can be ruined. The secrecy of 'the rules of the game' must nevertheless never happen without trust. A teacher who is not to be trusted can easily appear as a vulgar seducer who backs his words with a

\footnotetext{
5 The conditions that follow are suggestions based on the arguments I have presented in this essay. This is why I have formulated them in an assertive way, almost as a manifesto which demands a critical appraisal and a follow-up by 'hiin enkelte' reader.
} 
seductive smile, having an underlying agenda. The teacher must never forget that each person is a unique creation with an absolute integrity that must be respected. One must therefore never seduce from the position of personal interests, but always wish the best for the pupils, being well aware that good intentions don't always take something good with it.

\section{Seduction Versus Indoctrination}

The teacher ought to appear as an existential seducer instead of a teacher who indoctrinates the pupils. That makes a huge difference with regard to existential education. Suppose the teacher strived to get the upper hand by persuasion or to bring the pupils under control by persuasion, just as TV commercials or advertising. He would indoctrinate the pupils. Likewise, the teacher who wants to force the recipient to think in one way only, makes no room for individual participation. The problem with this indoctrinating strategy is that the recipient is being stripped of his right to choose on his own. Existential seduction, on the other hand, has the advantage that it neglects the moralistic or didactic forms that result in making the pupils servants to fixed ideas. Consequently, the existential seducer creates the opportunity for the pupils to have a joint influence in their own lives.

\section{Open for Choice}

The teacher's assignment does not consist of producing a singular and distinctive individual. This nevertheless doesn't deprive the teacher of the possibility to act. He can, for example, create dramatic conflict narratives through which the pupils are, in a seductive manner, drawn into the inside of new and foreign ways to relate to life. But the most important point is that these narratives do not possess an objective truth which the pupils will simply acquire. In all pedagogic situations where there is talk about existential themes, the teacher's communication must give an opening for choice, where either the receiver rejects the whole communication or decides to choose a new path in life. This also means that the communication has opened for a subjective truth, examples of which we can find in Kierkegaard's pseudonymous works. None of these works have an overall meaning and none of them can be treated as authoritative systems. These books do not warrant an allegorical reading and the reader should not search for an underlying meaning because they are full of amphibolies-linguistic booby-traps - that can be understood in more than one way. If, however, we are tempted to understand these works in a direct and straightforward way-as if these works always shall have the last word-we end up swallowing the bait. The pseudonymous works of Kierkegaard have no final conclusion, and this must also be the case in a teaching situation where existential education is the focus. The teacher can seduce the pupils to differing existential choices, but from then on they must be given an absolute freedom to choose what they will do.

Open Access This article is distributed under the terms of the Creative Commons Attribution Noncommercial License which permits any noncommercial use, distribution, and reproduction in any medium, provided the original author(s) and source are credited.

\section{References}

Adorno, T. W. (1996). Ästhetische theorie. [Aesthetic theory.] Frankfurt am Main: Suhrkamp.

Arcilla, R. V. (1995). For the love of perfection: Richard rorty and liberal education. New York, London: Routledge. 
Biesta, G. J. J. (1997). For the love of perfection: Richard rorty and liberal education by René Vincente Arcilla. Interchange, 28(1), 85-88.

Biesta, G. J. J. (1998). Say you want a revolution...suggestions for the impossible future of critical pedagogy. Educational Theory, 48, 499-510.

Biesta, G. J. J. (2009). On the weakness of education. In D. Kerdeman, et al. (Eds.), Philosophy of education 2009 (pp. 354-362). Urbana-Champaign, IL: Philosophy of Education Society.

Billeskov Jansen, F. J. (1951). Studier i Sфren Kierkegaards litterare Kunst. [Studies in Søren Kierkegaard's literary art.] København: Rosenkilde og Bagger.

Cappelørn, N. J. (2010). Splittelsen mellem idealitet og realitet. Om oppfattelsen af synd ognåde i Ibsens Brand med stadig baggrund i Kierkegaard. [The split between idealism and reality. On the understanding of sin and grace in Ibsen's Brand with constant background in Kierkegaard.] In N. J. Cappelørn, et al. (Eds.), Kierkegaard, Ibsen og det moderne. [Kierkegaard, Ibsen, and modernity.] Oslo: Universitetsforlaget.

Caputo, J. D. (2008). How to read Kierkegaard. New York, London: W. W. Norton and Company.

Davenport, J. J. (2008). What Kierkegaardian faith adds to alterity ethics: How levinas and derrida miss the eschatological dimension. In J. A. Simmons \& D. Wood (Eds.), Kierkegaard and levinas. Ethics, politics, and religion. Bloomington and Indianapolis: Indiana University Press.

Derrida, J. (1996). The gift of death (D. Willis, Trans.). Chicago and London: The University of Chicago Press.

Eisner, E. (2004). What can education learn from the arts about the practice of education? International Journal of Education and the Arts, 5(4), 1-11.

Garff, J. (2000). SAK Sфren Aabye Kierkegaard. En biografi. [SAK Sфren Aabye Kierkegaard. A biography.] København: Gads forlag.

Garff, J. (2008a). Dannelse, identitetsdannelse og dannelseskritikk. [Bildung, formation of identity, and critique of Bildung.] In J. Garff (Ed.), At komme til sig selv. 15 portratter af danske dannelsestankere. [Coming to oneself. 15 portraits of Danish thinkers of bildung.] København: Gads forlag.

Garff, J. (2008b). Forførerens forførelse. [The seducer's seduction.] In P. Götke (Ed.), Sprog og forførelse. Om sandhed og lфgn i religion og politik, litteratur og filosofi. [Language and seduction. On truth and lie in religion and politics, literature and philosophy.] Frederiksberg: Forlaget Alfa.

Ibsen, H. (1991). Samlede verker 2. [Collected works 2.] Oslo: Den norske bokklubben.

Kierkegaard, S. (1838/1997). Af en endnu Levendes Papirer. [From the papers of one still living.] In N. J. Cappelørn, J. Garff, J. Kondrup, A. McKinnon, \& F. H. Mortensen (Eds.), Søren Kierkegaards Skrifter, I. [Sфren Kierkegaard's Writings, I.] København: Gads Forlag.

Kierkegaard, S. (1843/1987). Either/or, volume 1. In H. V. Hong \& E. H. Hong (Eds.), Kierkegaard's writings, III. Princeton, New Jersey: Princeton University Press.

Kierkegaard, S. (1843/1983). Fear and trembling. In H. V. Hong \& E. H. Hong (Eds.), Kierkegaard's writings, VI. Princeton, New Jersey: Princeton University Press.

Kierkegaard, S. (1845/1988). Stages on life's way. In H. V. Hong \& E. H. Hong (Eds.), Kierkegaard's writings, XI. Princeton, New Jersey: Princeton University Press.

Kierkegaard, S. (1846/1992). Concluding unscientific postscript to philosophical fragments, volume I. In H. V. Hong \& E. H. Hong (Eds.), Kierkegaard's writings, XII. Princeton, New Jersey: Princeton University Press.

Kierkegaard, S. (1847/1995). Works of love. In H. V. Hong \& E. H. Hong (Eds.), Kierkegaard's writings, XVI. Princeton, New Jersey: Princeton University Press.

Kierkegaard, S. (1850/1991). Practice in christianity. In H. V. Hong \& E. H. Hong (Eds.), Kierkegaard's writings, XX. Princeton, New Jersey: Princeton University Press.

Kierkegaard, S. (1859/1998). The point of view for my work as an author. In H. V. Hong \& E. H. Hong (Eds.), Kierkegaard's writings, XXII. Princeton, New Jersey: Princeton University Press.

Kjær, G. (1986). Barndommens ulykkelige Elsker. Kierkegaard om Barnet og Barndommen. [Childhood's unhappy lover. Kierkegaard on the child and childhood.] København: C. A. Reitzels Forlag.

Sløk, J. (1993). Kierkegaard — humanismens tanker. [Kierkegaard—the thinker of humanism.] København: Hans Reitzels Forlag.

Spiecker, B., \& Straughan, R. (Eds.). (1991). Freedom and indoctrination in education: International perspectives. London: Cassell.

Strasser, T. (1981). The Wave. New York: Dell Laurel-Leaf.

Walsh, S. (2009). Kierkegaard. Thinking christianly in an existential mode. Oxford: Oxford University Press.

Westphal, M. (2008). Levinas and kierkegaard in dialogue. Bloomington and Indianapolis: Indiana University Press.

Wimmer, M. (2001). The Gift of Bildung. Reflections on the relationship between singularity and justice in the concept of Bildung. In G. J. J. Biesta \& D. Egéa-Kuehne (Eds.), Derrida and education. London and New York: Routledge. 